\title{
INNOVATION RATE OF CHANGE MEASUREMENT PART 1: INFORMATION TECHNOLOGY (IT)
}

\author{
L. R. Vega-González
}

Centro de Ciencias Aplicadas y Desarrollo Tecnológico (CCADET), UNAM Circuito Exterior S/N, Ciudad Universitaria, México, DF, CP 04510,

52-56228602 ext.1135, Fax 56228626

Irvg@servidor.unam.mx

Received: September $10^{\text {th }} 2004$, Aprobado: October $27^{\text {th }} 2005$

ABSTRACT

It is possible to characterize the different stages of history according the type of technology available. The last fifty years of human history have been referred to as "The Information Age" because of the great advancements and innovations of technology in electronics, computers and communications. The first part of this work presents a method based on the generation and exploitation of a database for the measurement of information technology gradients. The lack of the innovative data in earlier historic times is compensated by the consideration of the transport technologies as IT. The obtained result is a clear exponential growth curve. If the IT is driver of the global change, the notorious changes in the resulting graph can be related to the appearance of the Kondrattief cycles or "K" waves. Modelski [48] pointed out that the evolution of economic processes is closely related to the rate of growth in technological learning. According to the obtained results, the expected rate of change for IT innovation during the first two decades of the XXI Century will surely surpass the rate of change of technological learning. This will probably generate a non-sustainable system unless a change in the human consciousness occurs. Apparently, the sustainable evolution of the world system will depend on the appropriate technological selections, provoking the adjustment of innovation gradients to the rates of technological learning within the next generational cycles.

\section{RESUMEN}

Es posible caracterizar las diferentes etapas de la historia de acuerdo con el tipo de tecnología disponible. Los últimos cincuenta años de la historia humana han sido referidos como "la era de la información", debido a los grandes avances e innovaciones en las tecnologías de la electrónica, las computadoras y las comunicaciones. La primera parte de este trabajo presenta un método basado en la generación y explotación de una base de datos para la medición de los gradientes de las tecnologías de la información (TI's).

La falta de datos sobre las innovaciones en tecnologías de la información en épocas tempranas de la historia humana se compensa cuando consideramos las tecnologías de transporte como TI's. El resultado obtenido es una clara curva exponencial. Si las TI's son impulsoras del cambio global, los notorios cambios en la gráfica pueden relacionarse con la aparición de los ciclos de Kondratieff u ondas "K". Modelski [39] señaló que la evolución de los procesos económicos esta muy relacionada con la tasa de cambio del aprendizaje tecnológico. De acuerdo con los resultados obtenidos, la tasa de cambio esperada para la innovación de las TI's durante las dos primeras décadas del siglo XXI, seguramente sobrepasará la tasa de cambio del aprendizaje tecnológico. Esto, probablemente, generará un sistema no sostenible a menos que ocurra un cambio en la conciencia humana. Aparentemente la evolución sostenible del sistema mundial dependerá de la selección de las tecnologías apropiadas, lo que provocará el ajuste de los gradientes de innovación a las tasas de aprendizaje tecnológico dentro de los siguientes ciclos generacionales.

Key Words: Technology Rate of Change, Information Technologies, "K" Waves. 


\section{HUMAN PROGRESS AND INNOVATIONS RESEARCH}

The history of Humankind's development shows that throughout the centuries, technological innovations have been presented by a non-linear process of discoveries, inventions, developments and uses of new devices, tools, processes, and organizational working methods. The process, known as human progress, has been frequently associated with the concept of civilization. In the search of progress, man, unconsciously in many cases, has had almost always the objective of making his work easier and more efficient, while simultaneously promoting his wellbeing.

Therefore, it seems that one of the basic objectives of the constructive processes of civilization has been to improve the quality of human's life, although it has not always been this way and the desired outcome has not always occurred.

Research and analysis of technological change has been done focusing in economics, society, politics, history, product life cycle and technical capacities improvement.

Basalla [4] considers human progress to be a phenomenon of history based on the process of "technological evolution". He recognizes the existence of the biggest changes in human life associated with inventors and individual inventions as well as the existence of other series of smaller changes carried out along a considerable period. This dynamic situation has propitiated periods of intensive technological change and periods of relative stability. According to Pohlmann [52], there is no general rule how to organize sustainable innovation; for him first of all innovation is a product of the evolution of social systems. Thus, if technology change can be used as a measure of progress, we shall study and understand scientific and technological development as social processes, that is, processes that affect and are affected by social organizations [21].

Traditionally the theory of technological change has been related to economic growth, the economic production function, and cost analysis [18]. For example the unit cost of producing an important radically new IT product such as the telephone, radio, electronic computer, the semiconductors and the microchips, is very high because requires the invention of new tools and process equipment, higher standards of purity of materials, better quality control instrumentation and new variable skills; however IT products seem to follow Long Waves Innovation Models, with movement in mid term periods.

Another investigation line is on new product development. The biggest technological changes, generally, also give place to the proliferation of a great diversity of new products and devices. For this reason, they are known as breakthrough innovations [2]. The impact of the breakthrough innovations in the market and their use in society throughout human history has been the generation of changes in practically all aspects of life. These types of innovations changed the way individuals use to make things, improving their technical capacities dramatically. This phenomenon is known also as technological discontinuity [53]. In this regard, in modern times, some strategies have been needed to be implemented to manage technological discontinuity [60].

Utterback and Abernathy [65], as well as Abernathy et. al. [1] argue that at the early stage of a new product, the rate of innovation is high, shortening the product life cycle, stimulated by changing market needs. This is particularly true for IT innovations which occur day by day strongly impacting all human activities. For this reason it is very important to observe the gradient of this technology to develop social, economic, administrative and evolutionary impact and comparative studies.

\section{INFORMATION TECHNOLOGY (IT) AS DRIVER OF CHANGE}

Information technology is a broad domain that not only includes information and data processing but also voice, video and image applications and systems. IT is defined to include all aspects of computing and communication together with the hardware and software for management information systems, office support, transaction 
processing systems, decision support systems, executive information systems, telecommunication networks, internet, multimedia applications, database and data warehouses.

IT provides the means for the preparation, collection, transport, retrieval, storage, access, presentation and transformation of information in all forms: voice, graphics, text, video, and image [5].

In recent years, the application of IT to support and drive globalization of business has received increased attention. IT provides the ability to coordinate the activities of global dispersed employees, customers and suppliers; increases the efficiency and effectiveness of important organizational functions and processes; and manages data, information and knowledge across borders. IT innovation is therefore an important factor to create new competitiveness and business expansion [61].

Furthermore, the strategic management literature tends to regard innovations in telecommunication infrastructure and service supply as simply providing the nervous systems for industrial activity in the 1990's [45].

Intense innovation dynamics are the precedent of periods of technological revolution, for that reason the Whitworth J.E \& Rebstock's [68] study was directed toward accessing the Impact of Global Information Technology (GIT) applications.

Undoubtedly nowadays it is particularly strategic to develop the ability to measure and visualize the IT innovation dynamics. One of the purposes of this work is to find if long waves of IT innovation can be identified trough the development of a radical IT innovation measurement methodology.

\section{THE INFORMATION AGE}

The technological revolution concept allows us to divide up human history into different time periods. In Table I we can see that at present, human beings are living in a transition between the Information Age and the Cyberspace Age. This new technological revolution will perhaps be bigger than all previous ones and may propitiate a revolution of the human conscience, which progress will be measured in terms of computational power and available computers. This will deeply affect all aspects of life according Ravets \& Sardar [56\&57].

Different time periods in human history can be characterized by emergent and dominant sciences and technologies. Some outstanding examples can be seen in the third column of Table I. Probably the most impacting elements in daily life have been the means of transportation and transmission of information used by man.

Some decades ago, we began to experience the deep effects generated by IT [9]. The broader effects include those in the work place and throughout culture, while more specific effects include private entertainment and health, amongst many other aspects.

Throughout human history, auxiliary technology and resources have been used for establishing communication among individuals. For the purpose of this work, we will adopt the convention of defining the beginning of the "information age" as approximately in 1950 and continuing up to the present time. Nowadays, people talk about an "information society" and even an "information planet" [23\&64].

In this period, electronic, computer and communication systems have had the highest diffusion ever. In this work we also intend to demonstrate that during this period a great number of technological innovations in related areas have been presented, generating a new bunch of devices of electronic, computer and communication systems applied to all areas of life. The impact of the intense gradient of IT has helped to drive the globalization of all activities of human societies.

The starting point for the intense IT technological innovations process was the appearance of the most significant inventions after the Second World War. These were the digital electronic computer developed at the University of 
Pennsylvania by Eckert and Mauchly between 1944 and 1950 and the transistor developed and patented in 1948 by Shockley, Bardeen \& Brattain of the Bell Telephone Laboratories [3].

Table I.

Technological Revolutions in Scientific, Technological and Transmission Media of Information.

\begin{tabular}{|c|c|c|c|}
\hline Time Period & $\begin{array}{l}\text { Technological } \\
\text { Revolution (TR) }\end{array}$ & $\begin{array}{c}\text { Scientific and Technological } \\
\text { Characteristics }\end{array}$ & $\begin{array}{c}\text { Information and } \\
\text { Transmission Media }\end{array}$ \\
\hline $\begin{array}{c}\text { Pre Históric } \\
1.8 \text {-3500 B.C.E. }\end{array}$ & Not Defined & $\begin{array}{c}\text { Gathering of Foods, Hunting, } \\
\text { Rock Writing }\end{array}$ & $\begin{array}{c}\text { Stone, Fire, Smoke, Wood, } \\
\text { Mud }\end{array}$ \\
\hline $\begin{array}{l}\text { Civilization Begins } \\
3500 \text { B.C.E., } \\
\text { 2000B.C.E. }-500 \\
\text { B.C.E. }\end{array}$ & $\begin{array}{l}\text { Primitive } \\
\text { Agriculture }\end{array}$ & $\begin{array}{c}\text { Agriculture Crops domain } \\
\text { Geometry, Navigation, Botanic, } \\
\text { Astronomy }\end{array}$ & $\begin{array}{c}\text { Papyrus and Application of } \\
\text { Natural Inks with Birds } \\
\text { Feathers }\end{array}$ \\
\hline $\begin{array}{l}\text { Old Christian age } \\
500 \text { B.C.E/ } 1000 \\
\text { AD }\end{array}$ & $\begin{array}{l}\text { First Modern } \\
\text { Technological } \\
\text { Revolution }\end{array}$ & $\begin{array}{l}\text { Military Engineering } \\
\text { Mechanics } \\
\text { Cosmology } \\
\text { Astrology } \\
\text { Chemistry }\end{array}$ & $\begin{array}{c}\text { Chinese Paper Invented } \\
\text { (100 B.C.E.) } \\
\text { Printing invented }\end{array}$ \\
\hline $\begin{array}{c}\text { Middle \& Industrial } \\
\text { Ages- } \\
\text { 1500B.C.E./ } 1800 \\
\text { B.C.E.// } \\
\text { 1950 AD } \\
\end{array}$ & $\begin{array}{l}\text { Second Industrial } \\
\text { Modern TR }\end{array}$ & $\begin{array}{l}\text { Alchemy, Modern Science, } \\
\text { Industrial Technology, } \\
\text { Electricity, Steam Machine }\end{array}$ & $\begin{array}{c}\text { Fountain Pen } \\
\text { Boll Pen, Telephone, } \\
\text { Telegraph, Telefax, Xerox } \\
\text { Copier }\end{array}$ \\
\hline $\begin{array}{l}\text { 1950/2010 AD? } \\
\text { Information Age }\end{array}$ & $\begin{array}{l}\text { Beginning of the } \\
\text { Third Modern TR }\end{array}$ & $\begin{array}{l}\text { Electronics, Biotechnology, } \\
\text { Software and Communications } \\
\text { Technology Convergence }\end{array}$ & $\begin{array}{l}\text { Computers and Networks } \\
\text { (LAN; WAN), multimedia, } \\
\text { Internet, Opto-electronics } \\
\text { Communication Protocols }\end{array}$ \\
\hline $\begin{array}{c}\text { 2010/20?? AD } \\
\text { Cyberspace } \\
\text { Other... }\end{array}$ & Third TR & $\begin{array}{c}\text { Absolute Information Technology } \\
\text { Convergence Absolute Personal } \\
\text { Communications } \\
\text { Nanotechnology }\end{array}$ & $\begin{array}{c}\text { Ultra High Integration } \\
\text { Semiconductor Scale } \\
\text { Supercomputers, Quantic } \\
\text { Computers } \\
\text { Ultra Wide Band Digital } \\
\text { Standard Protocol }\end{array}$ \\
\hline
\end{tabular}

The aggregation of the transistor was the origin of intense development of the semiconductors, bringing to life the continuous improvement of high integrative scale chips (See Fig. 1). Semiconductors industry today is integrated by the collaboration between high technology firms, more modern and more competitive than the traditional large firms that are conforming dynamic networks [24].

Nevertheless, semiconductor technology is a clear example of the rewards from innovation, almost all mainstream semiconductor devices, such as DRAM's, began their lives as specialized design intensive products, pioneered by small US firms. The four kilobits programmable Read Only Memory (PROM) was one among many specialist memory devices pioneered by Intel. Between 1971 and 1981, twenty two chip manufacturers introduced some 203 separate microprocessor units based on Intel's original device.

The integration of these powerful microprocessors with dynamic higher capacity memory systems fosters and drives the innovative dynamics in data acquisition and management systems. The mainframe computer was developed using this combination during the 1960's. The personal computer was developed in the 1970's, and we will probably have quantum computers with capacities of 100×10'2 million of floating point operations per second (Petaflops) in the near future. 


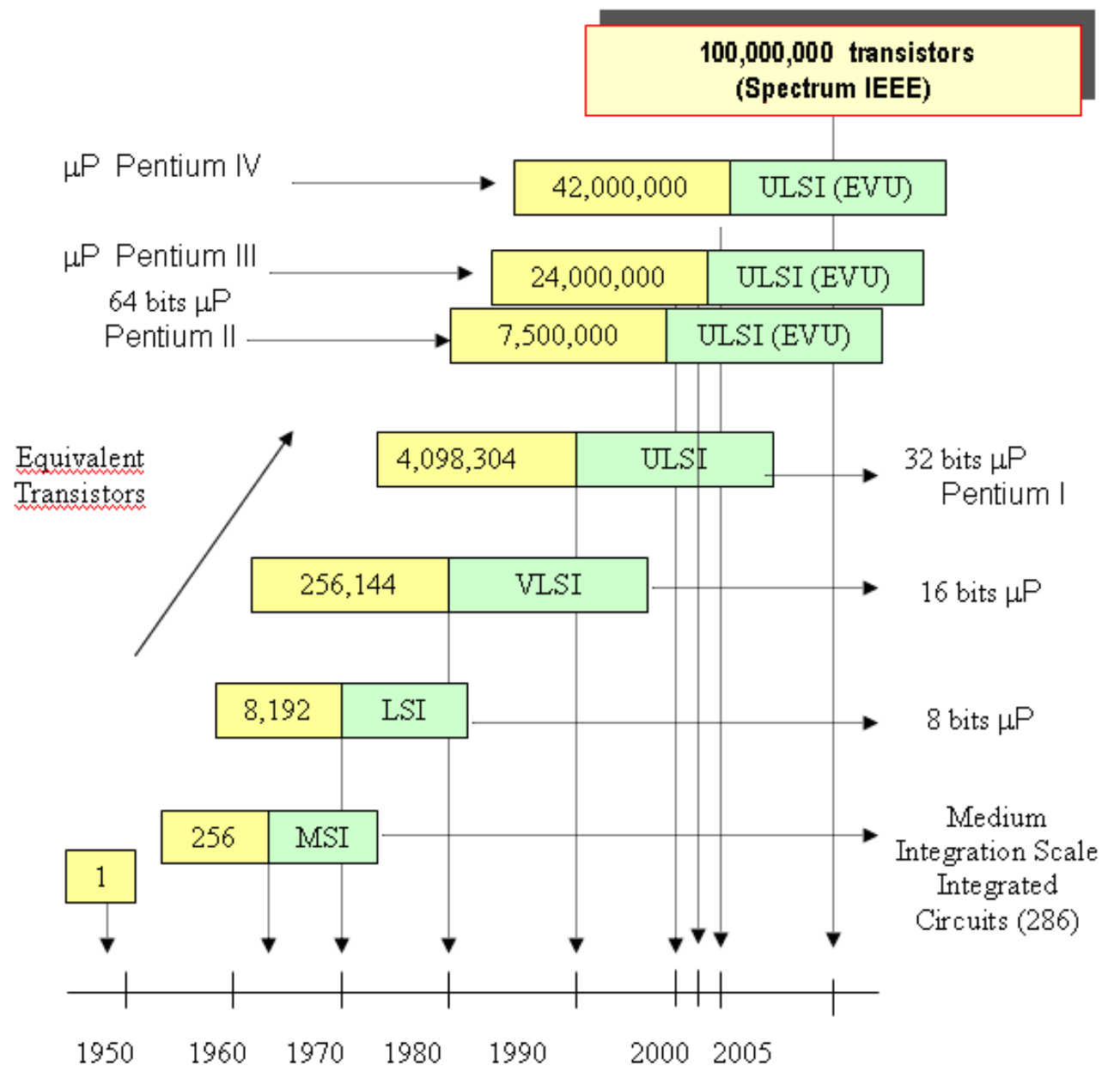

Figure 1. Evolution in Time of Semiconductor Integration Scales

One remarkable characteristic of the information age has been the development and use of networks and communication protocols. This propitiated the use of the Internet and multimedia systems. They are considered to be the technology that will energize the $19^{\circ}$ Kondratieff Cycle. This 19 " $\mathrm{K}$ " wave began in 1970 and according to Modelski [40] will define the communication industries in an Internet economy.

On the other hand, communication protocols in conjunction with the very high integration scale processor systems running applications over optical transmission wide band media, are generating changes in Internet technology that improve the quality of service in the new IP/WDM systems [54]. This technology will probably be the foundation of the third modern Technological Revolution.

Finally we also take in consideration as IT the Cawson's [10] Consumer Electronics typology as referred to a range of audiovisual products purchased by individual consumers primarily for leisure and entertainment, televisions and video recorders, digital audio tape, telecommunication networks. The Consumer Electronics include: stand alone products as electronic calculators and electronic watches; software dependent products with storage media: personal computers and games consoles; broadcast dependent devices as TV and Radio, and Network dependent as cellular Phones, Facsimile and videophone. 
The major characteristics of innovation process in Consumer Electronics are the continuous emission of quality and security standards, digital technology, the existence of systems or families of products rather than discrete products, the trend of the industry to be coalitions of firms and a convergence process. All of them, together, are eroding the boundaries between consumer electronics and related industries such as computing, telecommunications and professional electronics.

4. METHODOLOGY FOR MEASURING THE RATE OF CHANGE OF IT (dIT/dt)

For anyone interested in the measurement of technology, economic progress or the diffusion of innovations must be a central concern. Indeed, any study which relates economic growth and development with technological change, involves implicit or explicit assumptions about the way innovations, once originated in some points of the economic system spread over the system itself [44].

The measurement method presented is a modification of the Gellman Research Associates approach done in the United States. In their methodology they use literature as the primary source for defining the population of innovations. The universe of innovations is defined by consulting scientific and technical magazines; subsequently experts are consulted about the rating of these innovations [8].

Table II

Information Technology evolution database sample

\begin{tabular}{|c|c|c|c|c|c|}
\hline Entry No & $\begin{array}{l}\text { Date } \\
\text { B.C.E. }\end{array}$ & Place & $\begin{array}{r}\text { Technological Platform } \\
\text { Technological devices }\end{array}$ & A & $\mathbf{d T}_{\mathrm{A}} / \mathrm{dt}$ \\
\hline 1 & Paleolithic & All world & Fire & & ND \\
\hline 2 & 9000 & & Stone tools & & ND \\
\hline 3 & 8000 & & Plow thrown by oxen & & ND \\
\hline 4 & 7000 & & Oars ship & 3 & 0.003 \\
\hline 5 & 4000 & Mesopotamia & Irrigation Systems & & ND \\
\hline \multicolumn{4}{|c|}{$\Sigma($ Technological Gradients 10000-3500AC ) } & & 0.003 \\
\hline 6 & 3500 & Sumerian & Copper Tools & & ND \\
\hline 7 & 3500 & & Wheels Vehicles & 3 & 0.006 \\
\hline 8 & 3500 & All world & Palm leaves paper, oil & 3 & 0.006 \\
\hline 9 & 3500 & Sumerian & Cuneiform Writing & 3 & 0.006 \\
\hline 10 & 3200 & Europe & Cattle raising and Agriculture & & ND \\
\hline 11 & 3200 & North Europe & Marine Trade & 2 & 0.00667 \\
\hline 12 & 3200 & Alps & Pottery & & ND \\
\hline 13 & 3200 & & Spindles and Looms & & ND \\
\hline 14 & 3200 & & Stone Tools & & ND \\
\hline 15 & 3200 & & Hoe and Sickles & & ND \\
\hline 16 & 3000 & Mesopotamia & Pottery with lathe & & ND \\
\hline 17 & 3000 & Persia & Hieroglyphic & 3 & 0.015 \\
\hline \multicolumn{4}{|c|}{$\Sigma$ (Technological Gradients 3500-3000AC) } & & 0.03967 \\
\hline 18 & 2500 & Egypt & High sea sailboats & 2 & 0.004 \\
\hline 19 & 2250 & Egypt & Watering dams & & ND \\
\hline 20 & 2000 & Europe & Copper process & & ND \\
\hline
\end{tabular}

GRA employed a panel of five experts who rated approximately 1200 innovations on a 4 point scale, as follows, radical innovation, major technological change, improvement of existing technology and imitation of existing technology. Chakrabarti [7] used the same scale, but sought the help of a larger group of experts in a narrowly defined field. 
The documental based research has several problems; though it has a low cost, but it is extremely tedious and time consuming; some expertise are required to evaluate the item before one decides to incorporate it in the database; a certain familiarity with the technical area is required in the data collection process and one has to investigate the changes in editorial policy of a specific journal over the time to insure proper coverage of the field.

Our methodology is based on the construction and exploitation of a database (DB) that gathers basic information on the breakthrough innovations that have occurred throughout human history. The construction was done consulting specialized literature for several years. To carry out the DB it was necessary to revise, analyze and study some important sources of technological history to gather data on world technological development within the context of human history. [6, 11-17, 19-20, 25 - 43, 55, 66 - 67 \& 69]. A partial example of DB listing is shown in Table II. The total printed DB is about a hundred pages. In the DB sample the information technology quantification corresponds to "A" and $\mathrm{dT} / \mathrm{dt}$ columns.

The units of analysis adopted were radical innovations and technologies, assuming that some measurement problems can be overcome. For example, it is supposed that the adoption of a new technology is done more or less instantaneously, i.e. no diffusion lags exist. We also suppose that there is no slowness of imitation, that epidemic diffusion approach does not occur, and we don't take in account spatial analysis of diffusion.

The first objective was to identify insofar as possible, those radical innovations in information technology that substantially contributed to human development. The period of analysis starts about 3500 years before Christ (B.C.E), up to the year 2000 after AD.

The analyzed information showed that during the first centuries of this period of time, the development of information technology was scarce, therefore, for DB construction purposes we considered transport technology to be part of information technology, since the transportation resources have been facilitators of communication along human history. As a consequence, the DB included the following twelve fields:

1. Approximate or exact appearance dates for the technological innovation.

2. Place of occurrence.

3. A brief description of the type of device, system or innovation.

4. It is considered that information technology must include the following categories: electronics, software, computers, communications and in some centuries transport technology.

5. Differing from Gellman Research Associates methodology, we propose numeric value registrations to be quantified or weighed based on the impact that the technological innovation had in humanity, according to the following chosen values:

- Low impact innovation $\quad=1$

- Medium impact innovation $=2$

- High impact innovation $=3$

Since the idea was to obtain a source of numeric comparison, it was useful to assign arbitrary values. The values could have been 2, 4 and 6 or any others; however reliability resides in using the same approach for valuing all the radical innovations that have happened in every period of time of human history.

The only source of subjectivity is the analyst's approach to conform DB. For our purposes, bias is eliminated when the assumption stays constant along the construction of the whole database.

6. The innovative field DB value and another column were used to calculate the technological gradient, $\mathrm{dIT/dt}$. Since it was impossible to obtain continuous values, the technological gradient variable became discrete.

7. The gradient calculation was carried out by dividing the numeric value of the innovation among the number of years of previous time period in which the precedent radical innovation was presented. Of 
course, some suppositions were needed. For example, in the period going from the Paleolithic age until year 4000 before Christ, we considered that it took a maximum of a thousand years between periods for big innovations to appear. Later on, between 3500 B.C.E to 3000 B.C.E, appearances of the innovations lasted hundreds of years. According to the data, between the tenth and seventeen century A.D., dozens of years passed between the occurrences of innovations. The limit came when recorded data showed a year gap between innovations. Of course, today we can speak about hundreds of innovations daily. Some calculation examples:

- Between the years 8000 B.C.E to 7000 B.C.E. appeared the oars ship. This is an example of an innovation reported in a 1000 year period. In this example we divide by 1000 years. This way, this maximum impact transport innovation was valued at 3 units and registered in "A" column. Therefore the gradient value was calculated to be: $\mathrm{dIT} / \mathrm{dt}=3 / 1000=0.003$ innovation units per year.

- The appearance of the Sumerian "Cuneiform" writing tables were recorded on 3500 B.C.E. The corresponding value of this communication technology is 3 innovation units. The innovation reported in the previous period occurred approximately in the year 4000 B.C.E., so apparently it took about 500 years. The value of the corresponding gradient is: $\mathrm{dIT} / \mathrm{dt}=3 / 500=0.006$ innovation units per year.

- $\quad$ The 35 wire high impact telegraph appeared in Germany in 1809. Its assigned innovation value was 3 units. The previous innovation was carried out in 1808. For that reason we divided by one year to calculate the gradient. One year was the minimum dividing time for gradient calculation in all DB. Therefore the corresponding gradient is $\mathrm{dTI} / \mathrm{dt}=3 / 1=3$ innovation units per year.

- The "panchromatic movie " was patented in 1919 in the United States. In this case it was classified as a medium impact information technology. For that reason its assigned value was 2. DB reports several innovations during 1918, the previous year. Therefore we divided by one year. Corresponding gradient value was $\mathrm{dIT} / \mathrm{dt}=2 / 1=2$ innovation units per year.

8. To visualize the incremental effect of the gradient, values of the variables were partially added in pre assigned periods of time, in accordance with the readiness of data. Using this method, the technological gradients were totaled every 500, 100 or 10 years, or when necessary, in terms of the amount of the information. Table III shows the total IT and dIT/dt variables for the time periods considered.

9. Total values of IT and dIT/dt variables were used for building comparative graphs. The most abundant innovative information is reported in books for the period between 4000 B.C.E. and 1950 A.D. Moreover, we certainly know that the innovation dynamics increased from 1950 A.D. to 2002 A.D. However, we don't have enough information, because most of the current and new innovations are yet to be published in the books of technological history. To handle this problem, we used registered patents assuming that they are good indicators of global innovation activity. This procedure is continuously used in research. Jacob Schmookler [59] focused on inventions and patents to investigate the dynamic relationship between economic growth and development of technology since the 1960's and according to Sciberras [58], patenting activity can be used as indicator of technical strength.

10. The databases of US Patents were revised for technological information [62 \& 63]. The data obtained from the years 1976 to 2000 are presented in the Table IV. To include these data in our DB, we totalized the number of patents granted by the US Patents Office per year.

11. Later on, we had to take into account arbitrary compensation criteria because all of the granted patents will not become innovations. After carrying out some graphic equivalence tests to obtain comparable results to those obtained for previous time periods, we found that by dividing the number of patents into a thousand, we were able to obtain values of radical innovation equivalent to the previously reported values according to our measurement methodology described above. For example, 8874 patents related to information technology were granted in 1976. Using the compensation criteria, that number was converted and reported in our DB as 8.874 innovation units.

12. The arbitrary criteria chosen pragmatically means that globally speaking, for each thousand patents granted, a radical innovation comes to the scene. 
Table III.

$D B$ Summary values due to the addition of data in selected time periods

\begin{tabular}{|c|c|c|c|}
\hline Period Nr. & Time Period & Final year & $\boldsymbol{\Sigma}$ dIT/dt \\
\hline 1 & 10000 AC-3500 B.C.E & -3500 & 0.003 \\
\hline 2 & $3500-3000$ B.C.E & -3000 & 0.03967 \\
\hline 3 & $2500-2000$ B.C.E & -2000 & 0.012 \\
\hline 4 & $1500-1000$ B.C.E & -1000 & 0.08 \\
\hline 5 & 1000 AC-500 B.C.E & -500 & 0.02933 \\
\hline 6 & 500 AC-0 AD & 0 & 0.745 \\
\hline 7 & $0-500$ AD & 500 & 0.15 \\
\hline 8 & $500-1000$ AD & 1000 & 0.12 \\
\hline 9 & $1000-1500$ AD & 1500 & 0.78444 \\
\hline 10 & $1500-1600$ AD & 1600 & 0.1 \\
\hline 11 & $1600-1700$ AD & 1700 & 7.78846 \\
\hline 12 & $1700-1800$ AD & 1800 & 45.8667 \\
\hline 13 & $1800-1900$ AD & 1900 & 293 \\
\hline 14 & $1900-1910$ AD & 1910 & 70 \\
\hline 15 & $1910-1920$ AD & 1920 & 50 \\
\hline 16 & $1920-1930$ AD & 1930 & 79 \\
\hline 17 & $1930-1940$ AD & 1940 & 84 \\
\hline 18 & $1940-1950$ AD & 1950 & 55 \\
\hline 19 & $1950-1960$ AD & 1960 & 77 \\
\hline 20 & $1960-1970$ AD & 1970 & 100.65 \\
\hline 21 & $1970-1980$ AD & 1980 & 105.84 \\
\hline 22 & $1980-1990$ AD & 1990 & 184.163 \\
\hline 23 & $1990-2000$ AD & 2000 & 534.53 \\
\hline
\end{tabular}

Table IV

USA granted Information Technology Patents 1976-2000

\begin{tabular}{|c|c|c|c|c|c|c|c|c|c|c|c|c|c|c|c|c|}
\hline Year & Transport & Electronics & Microproc & Comms & Software & Automation & Robotics & Instrument & $\begin{array}{l}\text { Phone } \\
\text { Sist.. }\end{array}$ & $\begin{array}{c}\text { Satelite } \\
\& \\
\text { Auto }\end{array}$ & Planes & Trains & Ships & Spacecraft & $\begin{array}{l}\text { Rows } \\
\text { Total }\end{array}$ & $\begin{array}{c}\text { Data } \\
\text { Base } \\
\text { Points }\end{array}$ \\
\hline 1976 & 1727 & 1720 & 27 & 969 & 212 & 426 & 0 & 626 & 1532 & 1 & 215 & 854 & 458 & 107 & 8874 & 88.74 \\
\hline 1977 & 1648 & 1655 & 80 & 997 & 299 & 415 & 1 & 659 & 1623 & 0 & 204 & 824 & 383 & 81 & 8869 & 88.69 \\
\hline 1978 & 1633 & 1746 & 140 & 1038 & 295 & 419 & 0 & 600 & 1390 & 2 & 210 & 732 & 381 & 89 & 8675 & 86.75 \\
\hline 1979 & 1253 & 1378 & 136 & 732 & 268 & 319 & 1 & 473 & 997 & 0 & 143 & 514 & 273 & 69 & 6556 & 65.56 \\
\hline 1980 & 1582 & 1857 & 243 & 1027 & 465 & 401 & 2 & 626 & 1341 & 0 & 189 & 690 & 362 & 81 & 8866 & 88.66 \\
\hline 1981 & 1721 & 2119 & 385 & 1150 & 542 & 446 & 2 & 649 & 1402 & 0 & 233 & 709 & 391 & 87 & 9836 & 98.36 \\
\hline 1982 & 1521 & 1991 & 391 & 1127 & 599 & 398 & 3 & 618 & 1393 & 0 & 188 & 645 & 314 & 60 & 9248 & 92.48 \\
\hline 1983 & 1436 & 2071 & 399 & 1201 & 644 & 377 & 11 & 580 & 1349 & 0 & 203 & 585 & 300 & 85 & 9241 & 92.41 \\
\hline 1984 & 1752 & 2546 & 557 & 1480 & 979 & 475 & 31 & 744 & 1456 & 0 & 209 & 711 & 306 & 104 & 11350 & 113.5 \\
\hline 1985 & 1891 & 2787 & 605 & 1684 & 1311 & 631 & 73 & 741 & 1518 & 0 & 198 & 713 & 382 & 102 & 12636 & 126.36 \\
\hline 1986 & 1881 & 2934 & 610 & 1848 & 1470 & 620 & 116 & 742 & 1602 & 1 & 194 & 715 & 332 & 136 & 13201 & 132.01 \\
\hline 1987 & 2138 & 4106 & 735 & 2462 & 2045 & 888 & 164 & 1049 & 2054 & 3 & 235 & 782 & 438 & 177 & 17276 & 172.76 \\
\hline 1988 & 2104 & 3770 & 658 & 2418 & 2065 & 788 & 140 & 897 & 2144 & 6 & 215 & 667 & 350 & 145 & 16367 & 163.67 \\
\hline 1989 & 2643 & 4926 & 880 & 3358 & 3114 & 994 & 220 & 1265 & 2658 & 1 & 284 & 766 & 435 & 279 & 21823 & 218.23 \\
\hline 1990 & 2605 & 4721 & 798 & 3073 & 3081 & 997 & 203 & 1103 & 2243 & 2 & 244 & 775 & 417 & 248 & 20510 & 205.1 \\
\hline 1991 & 2677 & 5300 & 755 & 3392 & 3584 & 1086 & 185 & 1187 & 2258 & 1 & 274 & 802 & 483 & 231 & 22215 & 222.15 \\
\hline 1992 & 2828 & 5437 & 844 & 3739 & 4106 & 1129 & 195 & 1300 & 2395 & 1 & 322 & 833 & 496 & 219 & 23844 & 238.44 \\
\hline 1993 & 2919 & 5859 & 960 & 4304 & 4974 & 1225 & 228 & 1385 & 2799 & 0 & 292 & 754 & 490 & 247 & 26436 & 264.36 \\
\hline 1994 & 2941 & 6592 & 1087 & 5120 & 6101 & 1357 & 273 & 1469 & 3304 & 1 & 298 & 854 & 496 & 275 & 30168 & 301.68 \\
\hline 1995 & 3051 & 7163 & 1313 & 5860 & 7048 & 1373 & 278 & 1482 & 3896 & 1 & 324 & 870 & 543 & 262 & 33464 & 334.64 \\
\hline 1996 & 3433 & 8184 & 1683 & 7428 & 9268 & 1542 & 306 & 1657 & 4841 & 3 & 354 & 937 & 551 & 262 & 40449 & 404.49 \\
\hline 1997 & 3394 & 8751 & 1847 & 7712 & 10239 & 1662 & 320 & 1772 & 4960 & 1 & 394 & 1030 & 554 & 285 & 42921 & 429.21 \\
\hline 1998 & 4480 & 12590 & 2763 & 12238 & 16678 & 2409 & 507 & 2284 & 7871 & 1 & 542 & 1300 & 708 & 389 & 64760 & 647.6 \\
\hline $\begin{array}{l}1999 / \\
2000\end{array}$ & 8434 & 23696 & 5021 & 23838 & 32267 & 4619 & 893 & 4249 & 16043 & 1 & 877 & 2236 & 1370 & 737 & 124281 & 1242.81 \\
\hline Total & 61692 & 123899 & 22917 & 98195 & 111654 & 24996 & 4152 & 28157 & 73069 & 26 & 6841 & 20298 & 11213 & 4757 & & \\
\hline
\end{tabular}




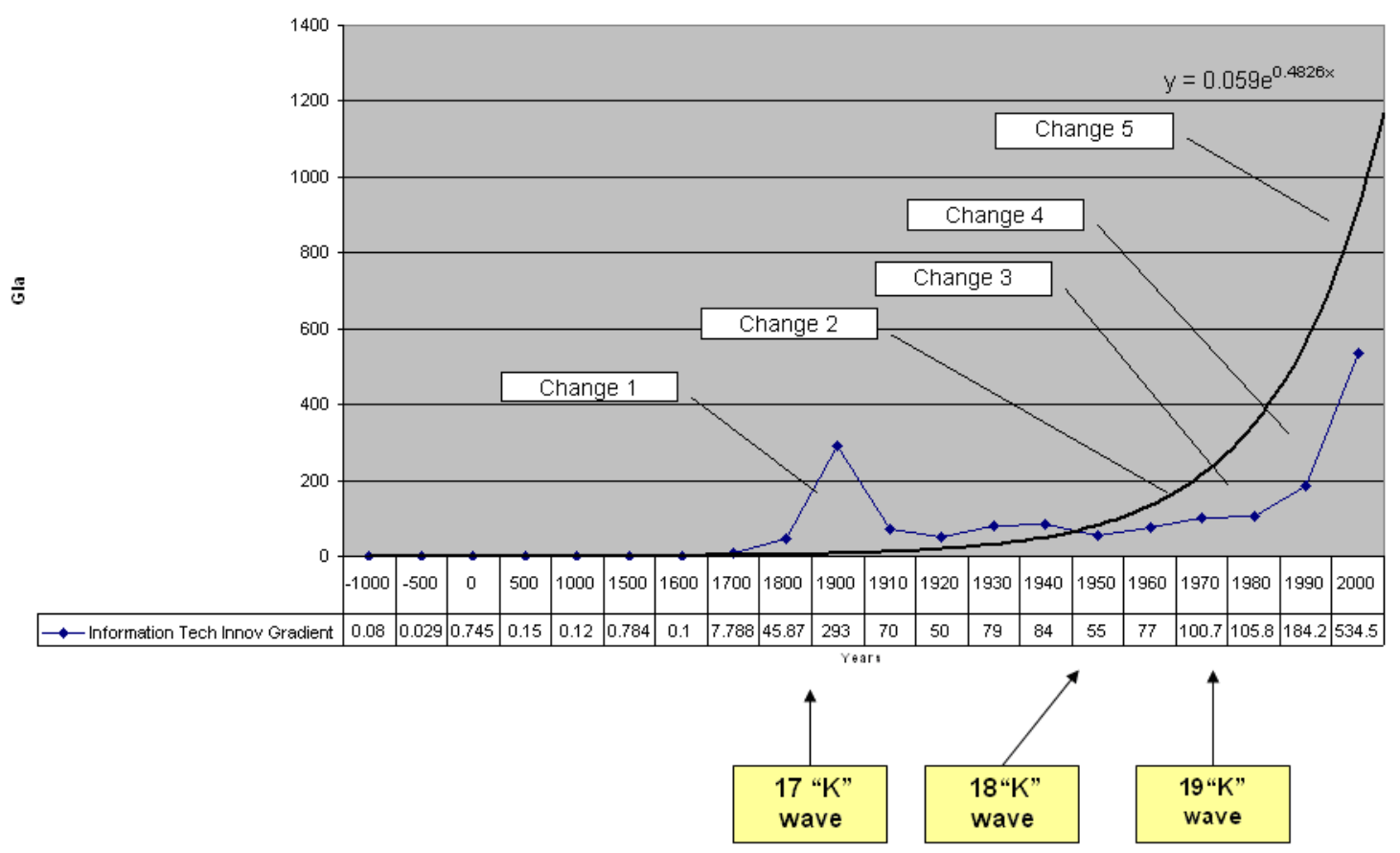

Figure 2. Information Technology Innovation Gradient

\section{DATA ANALYSIS}

Evolution of the built radical technological innovations database consists of more than 1300 entries. Fig. 2 shows the information technology gradient dIT/dt that corresponds to the Table III data and allows to observe the following outstanding behavioral aspects of information technology dynamics:

- The information technology innovation gradient is practically imperceptible from the beginning of current civilization considered to be 3500 B.C.E. until the mid-Eighteenth century. The first important slope change presented coincides with the second modern technological revolution best known as the industrial revolution propitiated by the steam machine.

- Before the mid-Eighteenth century, the number of radical innovations relatively increased. The second big change was observed between the mid -1960's and the mid -1970's and may be explained by the development of the transistor and the high scale integration semiconductors.

- A third slope change occurred between the mid 1970's and the mid 1980's and was certainly propelled by the intense development of computation systems.

- A fourth slope change is observed between the 1980's and the 1990's. This undoubtedly confirms the network systems and communication protocols strong drive of the IT innovations.

- Finally, from the early 1990's, information technology's radical innovation gradients seem to be explosive due to the tremendous impact of Internet and multimedia systems in all aspects of human life, including health, entertainment, research, food production, among many others.

\section{CONCLUSIONS}

The development of the IT measurement methodology was successful. The application of IT gradient measurements allowed us to justify the name given to the last half of the Twentieth Century as "Information Age". The validity and reliability of the measurement methodology was demonstrated since our results totally coincide 
with the main research results up to date, the economic "K" Waves cycles, and the Long and Mid Term Innovation Waves.

Referring to the graph in Fig. 2, one observes a series of pronounced slope changes recurrently coinciding with the cyclical process of economic development called "K" or Kondratieff waves, proposed by the economic theory.

Modelski [49] has carried out a revision of different "K" waves that have occurred throughout human history, according to the co-evolution of global politics and economics. According to his study, the first " $\mathrm{K}$ " wave occurred in China in 930 B.C.E. propelled by the printed paper. He also found that the "K-17" wave occurred in 1850 because of electric power and steel development, while "K-18" wave appeared in 1914 due to electronic and motor vehicles. "K-19" wave began in 1973 driven by the Internet. The last 3 "K" waves took place in the U.S. It is evident that the last two "K waves" are connected to IT breakthrough innovation.

It is generally believed that each "K" wave development time period takes about 50 to 60 years, including both positive and negative semi cycles [12, 46 \& 50].

Connecting the IT slope gradients shown in our Fig. 2 resultant graph, we can clearly observe the appearance of three big inflection changes identified as "K" waves and marked as K-17, K-18 and K-19. That could explain that geo economic and geo political global processes are apparently related to IT breakthrough technology at least for the last five decades. This process may continue during the first quarter of this century.

Analyzing the graph we also clearly see and identify two types of waves of Innovation. The Mid Term Waves which are observed between 1910 to 1950 and 1950 to 1990 and we can observe a Long Wave between the years 1900 to 2000. Our results coincide fairly well with the graph obtained by Mensch [47] and the Pohlmann's [52] results, in the sense that the 100 years Long Innovation Wave is apparently conformed by two 50 years Mid Term Innovation Waves.

Modelski and Devezas [16] predicted that K-20 wave will occur around the year 2025. It is very difficult to visualize which will be the technological breakthrough innovation that will start up this cycle. According to Halal, et. al. [22], technological prospective studies, for products for the second decade of the twenty-first century will include among others: optical computers, applied biochips, standard digital protocol, wide band networks, fiber optic cyberspace, tele-commutation and associated logistics, car- assembly intelligent materials, genetic therapy and on-line vision.

Using the exponential regression curve adjustment, represented by the continuous line in Fig. 2, we can make an approximately extrapolation forecast. The value of $\Sigma$ dIT/dt for 2020 year will be approximately 40,000 innovation units. A problem related to these dynamics behavior will be the required learning rate for new technological assimilation. "K" waves traditionally lasting 50 to 60 years are thought to have a learning period of two generations. Under this assumption humanity will only have two generational periods to assimilate all the technological innovations that will be present in that period. The results of this non tuned process are unknown.

However, when observing the behavior of the regression adjustment curve, the exponential growth indicates that the innovative processes and the granting patents will surely be intensified at extremely higher levels. The problem is discerning whether human being and their societies will be able to learn and manage the intensity levels of IT innovations that are to come.

By the end of the first decade of this century, according to Laszlo [43], humanity will enter into a new developmental trajectory in which the ideals of a sustainable evolutionary process for the third millennium will be that of connection, communication and changing of awareness. Connection and communication have been giving to us by intense IT development. The ideal changing of awareness would be the promotion of learning how to select the appropriate type of low-impact ecological technology that would sustain the survival of human species. We depend on technology for the production of the materials and goods required to satisfy our tangible or 
intangible necessities such as health and freedom. Nevertheless, such technology needs to be safe for the environment in which we live [51].

Through the intensive development of information technologies, we will definitely communicate and be connected with external resources. On the other hand, we need to generate a consciousness towards finding a better use and distribution of goods and technology. That would allow us to continue living in this world as human beings.

\section{REFERENCES}

[1] Abernathy, W. J., Clarck, K. B., Kantrow, A.M., (1983), Industrial Renaissance, Producing a Competitive Future for America, Basic Books, New York, EUA.

[2] Ayres R., OR; Technological Transformations and Long Waves. Part I, Technological Forecasting Social and Change. Vol. 37, pp1-37. Elsevier Publishing Co. (1990).

[3] Ayres R., OR, (1990), Technological Transformations and Long Waves. Part II, Technological Forecasting Social and Change, Vol. 36, pp111-137, Elsevier Publishing Co.

[4] Basalla G; (1991), The Evolution of Technology, Mexico: Editorial Grijalvo.

[5] Boar, B.H., (1994), Practical Steps for Aligning Information Technology with Business Strategies, John Wiley \& Sons.

[6] Borst Cornellius, (2000), Operating on to Beating Heart, Scientific American, Vol. 283; No.4, pp 46.

[7] Chakrabarti A.K., (1988), Trends in innovation and productivity: The case of chemical and textile industries in the US R\&D Management; Vol. 18 No. 2

[8] Chakrabarti A. K; (1989), Technology Indicators: conceptual issues and Measurement problems, Journal of Engineering and Technology Management, Vol. 6, pp. 99-116; Elsevier Science Publishers.

[9] Coates F. J., (1998), Business and Privacy in the Early 21st Century, Technological Forecasting Social and Change, Vol. 58, pp167-174, Elsevier Science Inc.

[10] Cawson A., (1996), Innovation and Consumer Electronics; in: The handbook of industrial innovation, Dodgson Mark, Rothwell R., Editors; Edward Elgar Publishing Ltd, Uk, pp. 145-153

[11] Concheiro A., (1975), "A Brief History of Automatic Control", Engineering Institute Series, UNAM, México.

[12] Dator J., (1999), From Tsunamis to Long Waves and Back, Futures, Vol. 31, pp123/133, Elsevier, Pergamon

[13] Derry T. K., Williams T., (1977), History of Technology from te Antiquity up to 1750, Ed. Siglo XXI, 19a Edition, México.

[14] Derry T. K., Williams T., (1977), History of Technology from 1750 up to 1900, No. I, Ed. Siglo XXI, 18a Edition, México

[15] Derry T. K., Williams T., (1977), History of Technology from 1750 up to 1900, No.II, Ed. Siglo XXI, 13a Edition, México

[16] Devezas T., (2001), Future Scenario: Fifth Kondratieff, http://demnet.ubi.pt/ ${ }^{\text {tessalen/scenario.htm }}$

[17] Electronic World, Supercapacitors, November 2000, pp842-845.

[18] Gomulka Stanislaw, (1990), The theory of technological change and economic growth, Routledge, London, New York.

[19] Grim B., (1975), The Timetables of History, Touchstone Books, Simon \& Schuster

[20] Grossman W., (2000), Bits of Radio, Scientific American, December.

[21] Hadjilambrinos C., (1998), Technological regimes: an analytical framework for the evaluation of technological systems, Technology in Society, Vol. 20, pp.179-194; Elsevier Science Ltd.

[22] Halal W. E., Kull M. D., Leffmann A., (1998), The George Washington University Forecast of Emerging Technologies: To Continuous Assessment of Technological Revolution, Technological Forecasting \& Social Change, Vol. 59, pp89-110, Elsevier Science Inc. 
[23] Heinonen S., Jokinen P., Kaivo-oja J., (2001), The Ecological Transparency of Information Society, Futures, Vol. 33, pp319-337, Elsevier Science, Pergamon.

[24] Hobday M., (1996), Innovation in Semiconductor Technology: the limits of the Silicon Valley Network Model; in The handbook of industrial innovation, Dodgson Mark, Rothwell Roy, Editors; Edward Elgar Publishing Ltd, UK, pp. 154-168.

[25] http://www.fht-esslingen-de/telehistory/define.html

[26] http://uww.fht-esslingen-de/telehistory/1840.html

[27] http://www.fht-esslingen-de/telehistory/1850.html

[28] http://www.fht-esslingen-de/telehistory/1870.html

[29] http://uww.fht-esslingen-de/telehistory/tv35-60.html

[30] http://uww.fht-esslingen-de/telehistory/transi30.html

[31] http://www.fht-esslingen-de/telehistory/sputnik.html

[32] http://uww.fht-esslingen-de/telehistory/radio30.html

[33] http://www.fht-esslingen-de/telehistory/microwave.html

[34] http://www.fht-esslingen-de/telehistory/future.html

[35] http://www.hartcourtcol.hottopic/genechips/html

[36] http://www.uspto.gov/patft/helpdb.htm

[37] Institute of Electrical \& Electronics Engineers, IEEE, Spectrum, Special Report, July 1999.

[38] Institute of Electrical \& Electronic Engineers, IEEE, (2001), News Briefs Computer: Innovative Technology for Computer Professionals, November 21-24.

[39] Infosystems,(1977), The Future for Facsimile, Monthly Report, Vol. 24 No. 75,

[40] James P., Thorpe N., (1994), Ancient Inventions, Ballantine Books, New York, USA.

[41] Jegalian K., (1999), The Gene Factory, Technology Review, March-April, pp64.

[42] Khaney L, (2000), "The Wireless Web", Scientific American, Vol. 283 No. 4pp 28.

[43] Laszlo E., (2001), Human Evolution in the Third Milennium, Futures, Vol. 33, pp649/658, Elsevier, Pergamon.

[44] Lissoni F., Metcalfe J.S., (1996), Diffusion of innovation Ancient and Modern: a review of the main themes; in The handbook of industrial innovation, Dodgson Mark, Rothwell Roy, Editors; Edward Elgar Publishing Ltd, Uk, pp. 106-144.

[45] Mansell R., (1996), Innovation in Telecommunication: Bridging the Supplier-User Interface, in The handbook of industrial innovation, Dodgson Mark, Rothwell Roy, Editors; Edward Elgar Publishing Ltd, Uk, pp. 232-253.

[46] Mallman C., Lemarchand G. A., (1998), Generational Explanation of Long Term Billow Like Dynamics of Societal Processes, Technology Forecasting Social and Change, Vol. 59, pp1-30, Elsevier Science Inc.

[47] Mensch G., (1974), Institutional barriers to the science and technology interactions, in H.F. Davidson et. al. (eds). Technology Transfer, Leiden: Nordhoff, p.215.

[48] Modelski G., (2001), What causes K - waves?, Technological Forecasting \& Social Change, Vol. 68 pp 75-80. Elsevier Science Inc.

[49] Modelski G. \& Thompson W., (1996), Leading Sectors and World Powers: The Co Evolution of Global Economics \& Politics, Columbia: University of South Carolina Press.

[50] Modis T., (1998), Limits to Cycles and Harmony in Revolutions, Technological Forecasting \& Social Change, Vol. 59 pp 33-38. Elsevier Science Inc.

[51] Nebbia G., (2001), Twenty Twenty-Five, Futures, Vol. 33 pp43-54, Elsevier Science Inc.

[52] Pohlmann Markus, (2005), The Evolution of Innovation: Cultural Backgrounds and the use of innovation models, Technology Analysis \& Strategic Management, Vol. 17, No. I, pp. 9-19.

[53] Prahalad; C. K., (1998), Managing Discontinuities, the Emerging Challenges, Research and Technology Management, pp14-22 
[54] Pereira Da Silva F., (2001), Internet Protocol (IP) over Wavelength Division Multiplexer (WDM), http://www.gta.ufrj.br/ fagundes/IP_WDM/ip_wdm.htm

[55] Pezcovitz D., (2000), Robotics Telesurgery: in the Waiting Room, Scientific American, December.

[56] Ravets J.R., (1995) Micro-Cybernetics Age to Revolution, Futures, Vol. 27, pp699-712

[57] Sardar Z., Ravets J., (1995), Cyberspace: To Boldly Go...; Futures, Vol. pp695-698.

[58] Sciberras E; (1983), New competition and technical change in the computer industry, Technovation, Vol.2, pp 17-26. Elsevier Scientific Publishing Company, Amsterdam.

[59] Schmookler, J., (1966), Invention and Economic Growth, Harvard University Press, Cambridge Mass. EUA.

[60] Stoelhorst, J.W., (2002), Transition Strategies for Managing Technological Discontinuities: Lessons from the History of the Semiconductor Industry, International Journal of Technology Management, Vol.23, No.4, pp261-286. Inderscience Enterprices Ltd.

[61] Suck-Chul Y., (2005), Technological Innovation as responding to business challenges; case study and theorization, International Journal of Technology Management, Vol. 29, Nos. 3/4, pp 295-307.

[62] The Royalty Rate Journal of Intellectual Property, Licensing Economics Review, No. 3, June, 1999, pp5

[63] http://uww.impi.gob.mx

[64] Truett A., W., (2001), The Information Planet: To Report on Our Trip to Another World, Futures, Vol. 33, pp437441, Elsevier Science, Pergamon.

[65] Utterback , J. M., Abernathy W. J., (1975), A Dinamic model of Process and Product Innovation, OMEGA Vol. 3, No. 6, pp. 639-56.

[66] Williams T., (1987), The History of Technology from 1900 up to 1950, No. I, Ed. Siglo XXI, 8a Edition, Mexico.

[67] Williams T., (1987), The History of Technology from 1900 up to 1950, No. II, Ed. Siglo XXI, 8a Edition, Mexico.

[68] Whitworth J.E; Rebstock W. S; (2005), Measuring the impact of global information technology applications, International Journal of Technology Management, Vol. 29, Nos. 3/4, pp 280-294.

[69] Yoffie D.B., Kwak M., (2001), Mastering Strategic Movement at Palm, MIT Sloan Management Review, Vol. 43, No. 1, pp55-63. 